International Journal of Business, Economics and Management

2022 Vol. 9, No. 1, pp. 1-19.

$\operatorname{ISSN}(e): 2312-0916$

$\operatorname{ISSN}(p): 2312-5772$

DOI: $10.18488 / 62 . v 9 i 1.2904$

(C) 2022 Conscientia Beam. All Rights Reserved.

check for
updates

\title{
THE IMPACT OF BRAND IMAGE ON LAPTOP PURCHASING INTENTION - THE MODERATING ROLE OF CONSUMER ETHNOCENTRISM
}

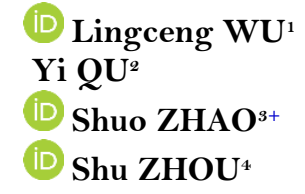

Article History

Received: 15 November 2021

Revised: 22 December 2021

Accepted: 5 January 2022

Published: 18 January 2022

\section{Keywords}

Brand image

Consumer ethnocentrism

Purchasing intention

Laptop

College students

Moderation effects.

JEL Classification:

D22; F23; G34.

\author{
${ }_{1,2,3,4}$ Dongbei University of Finance and Economics, Surrey International \\ Institute, Dalian, China. \\ 'Email:1044733015@gq.com Tel: 008613764859348 \\ [Email: quyijerry@dufe.edu.cn Tel: 008618624363658 \\ ${ }^{s}$ Email:shuozhao@dufe.edu.cn Tel:008615668669082 \\ ${ }^{*}$ Email: zhoushu@dufe.edu.cn Tel: o08613842625016 \\ ABSTRACT
}

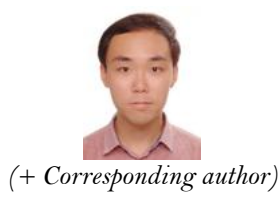

This paper aims to analyze the influence of laptop brand image on the purchasing intention of Chinese college students, and it further looks at the moderating role played by consumer ethnocentrism in the above causality, which helps to bridge the research gap in the domain. Employing the brand image theory and consumer ethnocentrism theory, and based on large-sample questionnaire surveys, this study reveals that brand image positively affects college students' purchasing intention of laptops, regardless of domestic or foreign laptop brands. What is more, besides playing a direct role in affecting purchasing intention, consumer ethnocentrism also plays a significant moderating role in affecting the effects of brand image on purchasing intention. It is found that high ethnocentric college students may not buy foreign laptops, even though the brand image of foreign laptops is superior. Overall, this paper has made important suggestions and implications for both corporate managers and policy makers.

Contribution/Originality: This study is one of very few studies which have investigated the influence of laptop brand image on the purchasing intention of Chinese college students, and based on consumer ethnocentrism theory, it further looks at the moderating role played by consumer ethnocentrism in the above causality.

\section{INTRODUCTION}

In recent years, the continuous increase in the number of college students and their rising consumption power are driving the consumption market of Chinese college students. According to Ministry of Education of the People's Republic of China (2018), the total number of Chinese general undergraduate and junior college students in 2017 is 43 million, and this number is growing at an annual rate of 2.7 percent. In addition, due to China's emerging economy, Chinese college students have strong purchasing power. IRsearch Consulting Group (2016) reported that the Chinese college student consumer market scale has exceeded 400 billion RMB in 2014, and this number was expected to increase at an annual rate of 5 percent. With the deepening process of internationalization, college students can now purchase laptops among domestic and foreign brands with a wide range of consumption needs, such as price, appearance and brand reputation. In other words, the competition between different laptop brands is growing more cut-throat. A well-communicated brand image can help to establish the position in the market, outstand in the competition, and improve the performance of the brand overall (Bian \& Moutinho, 2011). 
When consumers purchase commodities, in addition to brand image, consumer ethnocentrism also plays a significant role. Prior studies show that consumer ethnocentrism could adversely affect the sales of foreign products and even cause the boycott behavior against foreign brands (Lee, Lee, \& Li, 2017; Souiden, Ladhari, \& Chang, 2018). As to Shimp and Sharma (1987), people with high consumer ethnocentrism would suppose that buying foreign products can hurt the economy of the home country since it increases the sales profit of foreign investors. In addition, high ethnocentric consumers have strong preference of buying domestic products rather than foreign ones. There are several previous studies focused on the influence of consumer ethnocentrism on the purchasing behavior of consumers in developed countries. For instance, Wang and Chen (2004) stated that consumers in developed countries tend to have a higher quality perception of domestic than foreign products. For instance, in Germany, high consumer ethnocentrism can be a "safeguarding" for the domestic companies of Germany when these companies marketing their own products (Evanschitzky, Wangenheim, Woisetschläger, \& Blut, 2008). Nevertheless, there are quite a few researches regarding the influence of consumer ethnocentrism on the relationship between brand image and purchase intention of consumers in developing countries, so the importance of consumer ethnocentrism in the consumers' purchasing process should be valued by both domestic and foreign companies in China.

Previous literatures tend to focus on the direct impact of brand image in affecting consumers' purchase decision in different industries. This research contributes to complement the theories regarding the status of college students' consumer ethnocentrism and enrich the researches about the influence of brand image, consumer ethnocentrism as well as its moderating effect on consuming decisions of Chinese college students consumer group from the perspective of laptop brands. Additionally, it makes up the deficiency that few researches empirically compare the differences between college students who buy domestic brand laptops and those who buy foreign brand laptops. Furthermore, this study also contributes some suggestions to the laptop companies in China based on the findings, which are effective for both domestic and foreign companies to grasp the college market.

\section{LITERATURE REVIEW}

\subsection{Brand Image}

Brand image has been recognized in many literatures as an essential field of consumer behavior and marketing (Lee, Leung, \& Zhang, 2000; Ogba \& Tan, 2009; Plumeyer, Kottemann, Böger, \& Decker, 2019), while there is no uniform definition of brand image (Bian \& Moutinho, 2011). Conventionally, from the psychological perspective, brand image refers to perceptions about a brand as reflected by the brand associations held in consumer's memory (Keller, 1993); these associations could originate from customers direct experience or from information obtained on a market offering or due to the impact a pre-existing association with an organization had on consumer (Ogba \& Tan, 2009). Similarly, as to Biel (1992), brand image is a combination of attributes and associations related to a brand in consumers' mind. In addition, from the symbolization perspective, Nöth (1988) stated that commodities are studied as signs whose meaning is brand image. As for enterprises, brand image is an exclusive and targeted brand atmosphere created by enterprises to meet market demands Xue (2018). Further, Liang (2015) proposed that brand image is a manifestation of consumer personality, such as mascot. This study adopts Biel's definition.

It has shown in many researches that brand image can have a great impact on consumer behavior in different industries. Positive brand image evolves when individuals have a unique, favourable and strong association of the brand, which impacts attitudes towards the brand and drives consumer behaviour (Johansson, Koch, Varga, \& Zhao, 2018). Within Chinese mobile phone market, brand image has positive impact on customer expression of loyalty and commitment to market offering (Ogba \& Tan, 2009). In other words, brilliant brand image can make consumers purchase the products of the same company over and over again, and the companies can gain stable passengers in the market. Furthermore, as for Chinese sportswear market, Tong and Li (2013) empirically proved that positive brand personality, which is an essential aspect of brand image, enjoys positive strong purchase intentions in China 
regardless of whether it is domestic or foreign and whether the product is made domestically or overseas. Similarly, in the sneakers market, Mai (2013) pointed out that building a positive brand image is extremely significant for companies to increase the purchase intention of consumers for sneakers. In addition, the importance of brand image on the consumers' purchase intention can also be affirmed in other industries. For instance, as to different brands of watches, the better the brand image is, the more consumers identify with the product; accordingly, the stronger the willingness of consumers to buy the watches (Tian, 2014). Also, the impact of brand image on the purchase intention of consumers can be also applicable to interpret consumers' consuming behavior for cosmetic brands. Nevertheless, Peng (2017) analyzed the impact of brand image on consumers' purchase intention in the Chinese study abroad training industry from four dimensions which are corporate image, service image, user image and symbolic image; and she found that user image had no huge impact on consumer purchase intention. So this study proposes the following hypotheses:

Hypothesis 1. Brand image has a positive impact on Chinese college students' purchase intention of laptop brands.

Hypothesis 2. Brand image has a positive impact on Chinese college students' purchase intention of domestic laptop brands.

Hypothesis 3. Brand image has a positive impact on Chinese college students' purchase intention of foreign laptop brands.

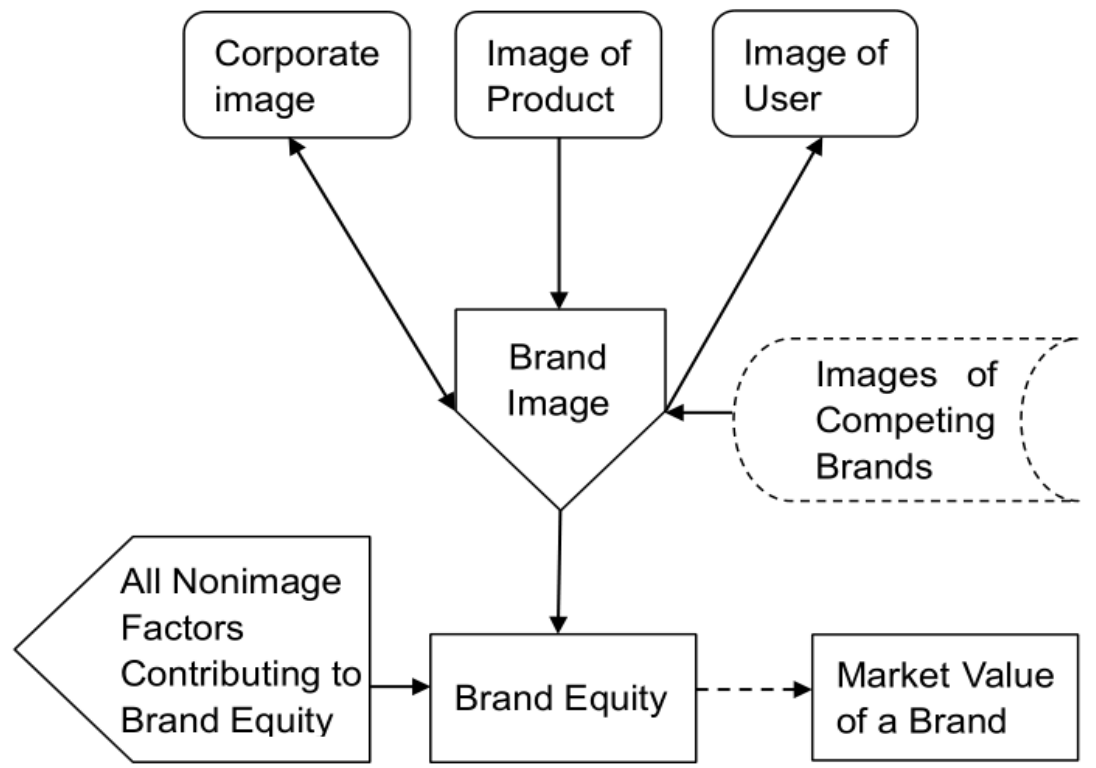

Figure 1. The three components of brand image (Biel, 1992).

As to Biel (1992), brand image can be described as having three components influenced by soft and functional attributes: the image of provider of the product or service, or corporate image; the image of users; and the image of product or service (See Figure 1). First of all, corporate image means the sum of perceptions about an organization reflected in the associations held in consumer memory (Keller, 1993) Notably, these perceptions are composed of emotional, functional and symbolic components (Cian \& Cervai, 2014). Corporate image is the key to companies to attract and retain consumers. Andreassen and Lindestad (1998) proposed that corporate image is the primary path to customer loyalty and customer satisfaction. Thereby, good corporate image can stimulate consumers to buy commodities. Second, product image is a physical object which can satisfy the emotional needs of consumers (Wang, 2011). However, Yang and Sun (2013) defined this term as an external representation of product brand and consumers' overall perceptions on product brand, including internal quality image of the product. According to Yang (2006) positive product image can raise the company's profile and enhance brand image, therefore increase customer loyalty. As a result, favorable product image enhances consumers' purchase intention. Third, user image refers to the soft attributes such as personality and the hard attributes showing some fundamental information of users such as age and occupation (Biel, 1992). Many consumers usually link one brand to specific users (Cao \& Fu, 
2012). These specific users are also named reference group. Bearden and Etzel (1982) found that reference group can influence on product and brand purchase decisions. So if the users of the product have similar soft and hard attributes, such as lifestyle and income level, the product will attract more potential consumers to purchase. Based on the theories above, this study proposes the following hypotheses:

Hypothesis 2a. Corporate image has a positive impact on Chinese college students' purchase intention of domestic laptop brands. Hypothesis 2b. Product image has a positive impact on Chinese college students' purchase intention of domestic laptop brands. Hypothesis 2c. User image has a positive impact on Chinese college students' purchase intention of domestic laptop brands. Hypothesis 3a. Corporate image positively influences the college students' purchase intention of foreign laptop brands. Hypothesis 3b. Product image positively influences the college students' purchase intention of foreign laptop brands. Hypothesis 3c. User image positively influences the college students' purchase intention of foreign laptop brands.

\subsection{Consumer Ethnocentrism}

Consumer ethnocentrism is the beliefs held by consumers about the appropriateness, indeed morality, of purchasing foreign made products (Shimp \& Sharma, 1987). In this regard, foreign products can be big trouble to ethnocentric consumers and countries, since they could cause countries to teetering on the edge of recession and reduce domestic employment opportunities. Also, ethnocentric consumers suppose that it is immoral to purchase products from other countries. Hence, ethnocentric consumers, especially developed country consumers, are more likely to focus on the strengths of domestic products and to neglect the positive attributes of foreign products (Shimp \& Sharma, 1987; Wei, 2008). On the other hand, the representation of consumer ethnocentrism can be fluid in developed countries. For example, Wei (2008) noted that Japanese consumers evaluate homemade products more favorably than foreign products, no matter how superior the foreign products are. Additionally, the impact of consumer ethnocentrism in developing countries may vary with domestic economic development. Reardon, Miller, Vida, and Kim (2005) stated that in the newly transitioning economy, ethnocentrism can raise consumers' negative views on advertisements of foreign products, and thus indirectly increase their negative views on foreign brands.

In existing literatures, there are several differences between developed country consumers and developing country consumers on their purchase behavior of domestic products. In developed country, consumers love domestic products mainly due to the products' higher quality (Yen, 2018). Contrarily, in developing countries, consumers prefer imported products to domestic, even high ethnocentric consumers may not suppose domestic products are of higher quality than imported ones (Wang \& Chen, 2004). China, like other developing countries, consumer ethnocentrism is low (Ding, 2017).

Many Chinese consumers evaluate foreign products with specific attributes, such as brand image (Yen, 2018) and price (Wei, 2008). Some Chinese people desire famous international brands with symbolic meanings (e.g. wealth and status) to feel satisfying about themselves (Tong \& Li, 2013). In developing countries, consumer ethnocentrism can raise the positive effects of perceived quality and perceived brand image on the willingness to buy domestic products (Yen, 2018). In addition, the influence of consumer ethnocentrism on consumer willingness to purchase varies with industries.

For example, Xu, Xu, Chen, and Wang (2017) empirically demonstrated that the growth of consumer ethnocentrism can increase consumers' willingness to pay for infant formula in China. Nevertheless, Chinese consumers' ethnocentrism has no significant impact on consumers' intentions to buy either domestic or foreign sportswear brands (Tong \& Li, 2013). So this study proposes the following hypotheses:

Hypothesis 4. Consumer ethnocentrism has an impact on Chinese college students' purchase intention of laptop brands.

Hypothesis 5. Consumer ethnocentrism has a positive impact on Chinese college students' purchase intention of domestic laptop brands.

Hypothesis 6. Consumer ethnocentrism has no impact on Chinese college students' purchase intention offoreign laptop brands. 


\subsection{The Moderating Effect of Consumer Ethnocentrism}

As mentioned above, favorable brand image may influence consumers' willingness to purchase. However, consumers with distinct levels of consumer ethnocentrism may have different purchase decisions when buying domestic and foreign products. First, consumer ethnocentrism may affect the relationship between brand image and consumers' purchase intention of domestic products. As previously noted, consumers in developing countries have more willingness to buy imports because of high quality and fashionable brand image (Wang \& Chen, 2004). However, following the similar line of thought, as for high ethnocentric customers, purchasing imports is immoral and it could even reduce sales of domestic products. Therefore, even though some foreign products have a more attractive and shinning brand image compared with domestic products, high ethnocentric customers would have a sense of responsibility to purchase domestic products. On the contrary, low ethnocentric consumers may prefer to buy imports which have a more fashionable brand image.

Moreover, when consumers face foreign products, consumer ethnocentrism may negatively moderate effect on the influence of brand image on consumers' purchase intention. In China, consumer ethnocentric sentiment is rising (Ding, 2017). In other words, consumer ethnocentrism is becoming one of the significant factors that influence Chinese consumers' consuming behaviors. Additionally, the consumer ethnocentrism of young people varies with Asian countries. For example, Chinese consumers, especially young college students, are more ethnocentric than Koreans (Han, 2017); whereas Japanese people generally feel more confident about domestic products than imports (Wei, 2008). Moreover, compared with older people, young Asian consumers are more individual in making purchase decisions (Han, 2017). Thus, high ethnocentric consumers, especially young Chinese people, can be firmly not buy foreign products due to the strong sense of responsibility for supporting domestic products. Therefore, this study proposes the following hypotheses:

Hypothesis 7. Consumer ethnocentrism moderates the effect of brand image on Chinese college students' purchase intention of laptop brands.

Hypothesis 8. Consumer ethnocentrism positively moderates the effect of brand image on Chinese college students' purchase intention of domestic laptop brands.

Hypothesis 9. Consumer ethnocentrism negatively moderates the effect of brand image on Chinese college students' purchase intention of foreign brands.

\subsection{Chinese College Students' Purchase Behavior}

Many previous researches mainly focus on the influence of perceived price, brand image and consumer ethnocentrism on Chinese young people's purchase intention, whereas few researches show the moderate effect of consumer ethnocentrism on college students' purchase behaviour. Compared with old people, young people (age 20 to 30) are more brand-sensitive and they generally have lower than consumer ethnocentrism older people, because they grew up with much more family income and advertisements of both global and local brands (Wei, 2008). Although the Chinese youth think patriotism is extremely important, they seem not to consider patriotism or consumer ethnocentrism as a main factor that influence their purchase decisions (Tong \& $\mathrm{Li}, 2013$ ). According to Ran (2010), Chinese undergraduate students and other adults have more consumer ethnocentrism than high-school students, and the price difference between foreign goods and domestic goods plays a positive moderating role between consumer ethnocentrism and purchase intention of domestic goods. Consistently, Cai (2009) empirically proved that perceived price negatively influences undergraduate students' purchase intention of laptops, while brand image positively affects undergraduate students' purchase intention of laptops. In addition, since Chinese young people are sensitive about brand (Wei, 2008), strengthening a brilliant brand image in college students' eyes is very significant for enterprises to gain the specific market of young people. So brand image can influence the Chinese college students' purchase intention, while consumer ethnocentrism may not have a moderating impact for the Chinese college students' purchase decisions. This study aims to analyze the influence of brand image and 
consumer ethnocentrism on Chinese college students' purchase intention of laptops as well as its moderating effect. Figure 2 shows all the hypotheses and assuming relationships.

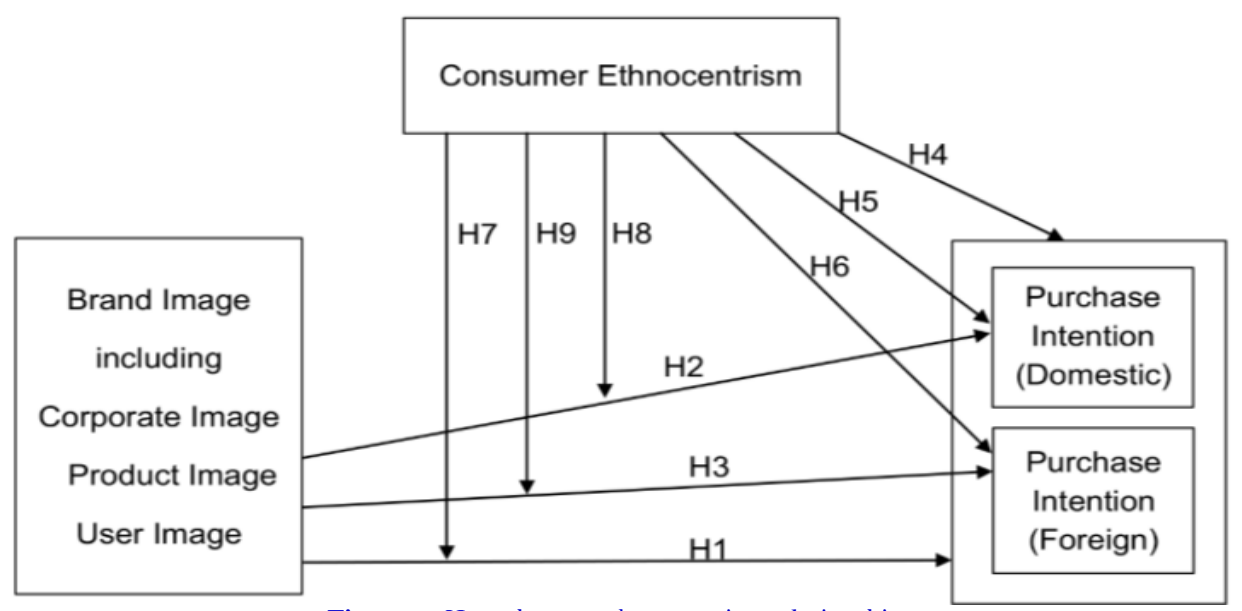

Figure 2. Hypotheses and assumption relationships.

\section{METHODOLOGY}

\subsection{Data}

This study uses literature survey, descriptive and explanatory research methods to collect data and design the self-administered questionnaire. Descriptive research is to portray accurate profiles of persons, events or situations (Saunders, Lewis, \& Thornhill, 2010). This method can also be used to describe the characteristics of the market and thereby make some specific hypotheses. In the explanatory research, this study applies quantitative method to analyzed data. Since the research subjects are Chinese college students, the questionnaire is designed with Chinese. This questionnaire consists of four parts. The first part includes the demographic questions regarding gender, academic degree, age and monthly disposable income of respondents and the names of 20 domestic and foreign laptop brands to choose from. Respondents are asked to choose the laptop brands that they are using at present, so that this study can obtain the latest and real brand image of laptops. If they do not find appropriate options, they can enter the name of their laptop brands. The second part is to measure brand image with three dimensions of corporate image, product image and user image. Specifically, each dimension consists of three items which are modified from Biel (1992) and Wang (2018). The third part and the fourth part focus on the purchase intention and consumer ethnocentrisms respectively. Each part includes three items, which are revised from Yen (2018). All items are described with a five-point Likert scale. The five options are "strongly disagree", "slightly disagree", "normal", "slightly agree" and "strongly agree", which are assigned with 1, 2, 3, 4 and 5 respectively. To ensure the accuracy of answers and not make respondents feel confused, each part is separated with a specific name. In terms of secondary research, literature survey methods are used to do literature review from many academic websites, such as Emerald, Springer and JSTOR, and then develop research hypotheses and design the questionnaire.

The research objects of this study are Chinese college students. This group includes junior college students, bachelors, masters and doctors. Additionally, this study adopts online questionnaire, which can be distributed widely, save a lot of time, and make the data be quantified easily, although it may also produce some invalid data if the respondents are careless. After collection, this study applies SPSS (24.0) as an instrument to do reliability test, factor analysis, correlation analysis and regression analysis to examine and compare the data. Eventually, 446 questionnaires were recycled and there are 70 invalid questionnaires, which include: 1) the respondents do not choose or enter the name of laptop brands; 2) the answers of questionnaire are almost the same and it seems that the respondents fill them at random. The effectiveness rate of questionnaire is $84.3 \%$. 


\subsection{Measurement of Variables}

\subsubsection{Control Variables}

For control variables, the characters of respondents are measured by gender, academic degree, age and monthly disposable income. These variables are recognized as other variables that can influence the purchase intention of consumers in addition to the brand image product and the level of consumer ethnocentrism of consumers.

\subsubsection{Independent and Moderating Variable}

For independent variables, this study adopts three dimensions which are corporate image, product image and user image to measure the brand image of laptops. Specifically, these dimensions include hard factors such as size of business, performance of product and level of education, and soft factors such as the design of products and the personality of consumers (Biel, 1992). In addition, for the features of laptop market, this study adds "the research and development capability of the company" which complemented by Jiao (2007) to evaluate the corporate image of laptop companies. Furthermore, consumer ethnocentrism is both the independent variable and the moderating variable, and this study capture consumer ethnocentrism from the aspect of impactive economic effect of buying foreign products and the necessity of buying domestic products.

\subsubsection{Dependent Variables}

For dependent variables, this study uses three questions which are "the likelihood of buying the products of this brand", "the willingness to buy products compared with other brands" and "the possibility of buying products of this brand in the near future" to capture the purchase intention of college students.

\section{DATA ANALYSIS}

\subsection{Descriptive Statistics}

In the sample, male accounts for $36.4 \%$ with the number of 137 , and female accounts for $63.6 \%$ with the number of 239, so there are more women than men in the sample. As for academic degree, the main part of sample is bachelor, which accounts for nearly $80 \%$. This percentage of junior college students is around $8 \%$, and this number is $4 \%$ less than the total percentage of masters and doctors. In addition, the age of the sample is mainly from 19 to 23, and the number of respondents aged between 19 and 26 are 326. As to monthly disposable incomes, 45 percent of respondents have the monthly disposable incomes reaching up to RMB 1000-2000. The percentages of respondents who has RMB $2000-3000$ and over RMB 3000 monthly disposable income are balanced, with $22 \%$ and $23 \%$ respectively. As to the brand of laptops, there are 182 respondents use foreign laptops and 194 respondents use domestic laptops, with $48 \%$ and $52 \%$ respectively, as can be seen from the Figure 3 below.

\section{- Foreign Brand $\quad$ Domestic Brand}

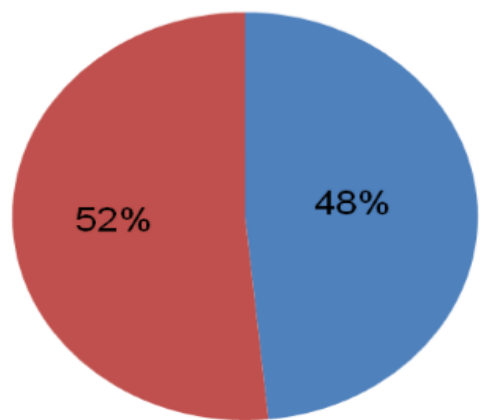

Figure 3. The brand usage of laptops in the sample. 
The mean scores of corporate image, product image and user image are 4.03, 3.68 and 3.41 respectively, which means that the brand image of domestic and foreign laptops are slightly excellent in respondents' mind. Furthermore, the mean score of consumer ethnocentrism is 1.8, so the level of consumer ethnocentrism is low among the college students in China. This result is consistent with Ding (2017), which shows that developing countries, especially China, have low consumer ethnocentrism. What is more, the mean score of consumer ethnocentrism among males (1.96) is a little higher than that of consumer ethnocentrism among females (1.75), as can be seen from the Figure 4 .

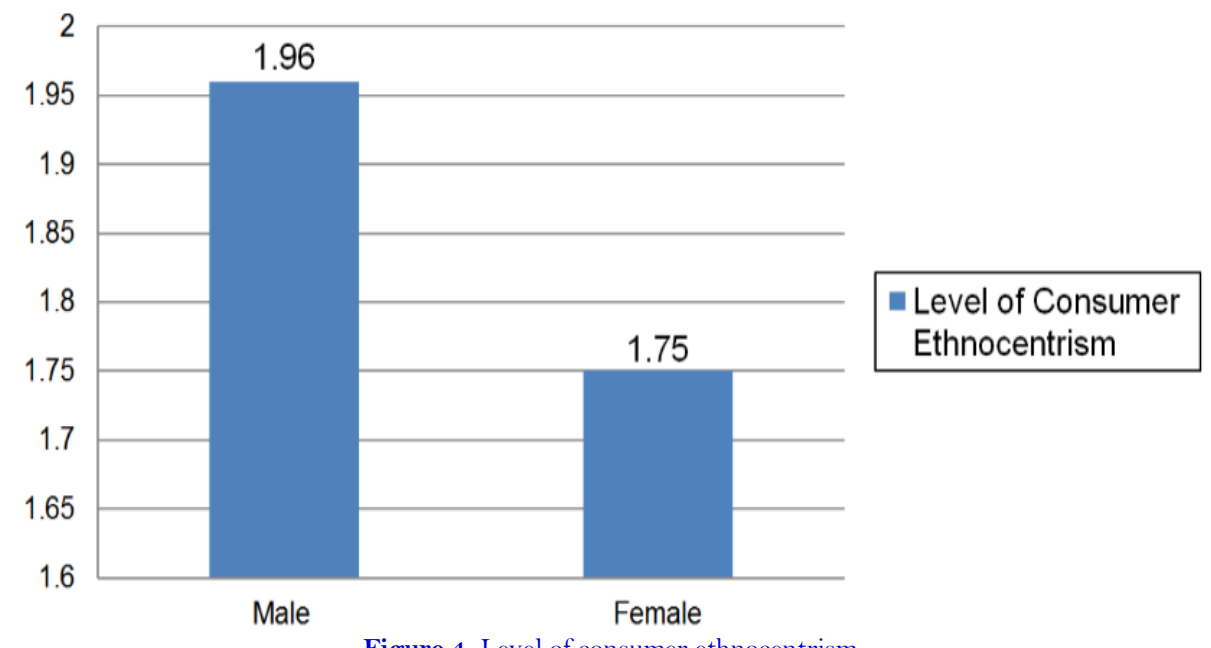

Figure 4. Level of consumer ethnocentrism.

\subsection{Reliability and Validity Test}

The reliability analysis and factor analysis using SPSS (24.0) are performed to test the reliability and validity of measurements. As for reliability analysis, this study uses the number of Cronbach's $\alpha$ value to judge the reliability of the questionnaire and collected data. If the Cronbach's $\alpha$ value is above 0.70, the reliability of the scale is high (Zhou, 2014). According to the data shown in Table 1, the Cronbach's $\alpha$ value for the whole questionnaire is 0.841. As a result, the reliability of the whole scale meets the requirements for academic research. In detail, the Cronbach's $\alpha$ value for four coefficients which are the coefficients of corporate image, user image, purchase intention and consumer ethnocentrism are all above 0.70; moreover, one coefficient is above 0.50, so the questionnaire is reliable.

Table 1. Reliability analysis results.

\begin{tabular}{c|c|c}
\hline Factor & \multicolumn{2}{|c}{ Cronbach's a Value } \\
\hline Corporate Image & 0.788 \\
\hline Product Image & 0.511 \\
\hline User Image & 0.762 \\
\hline Purchase Intention & 0.934 & \multirow{2}{*}{0.841} \\
\hline Consumer Ethnocentrism & 0.895 & \\
\hline
\end{tabular}

For validity test results, because all dimensions and items of this study are based on the many previous literatures and theories, content validity meets the requirement of questionnaire. Furthermore, this study uses factor analysis to examine construct validity. Lin and Lu (2010) stated that if the factor loadings of the measuring questions are higher than 0.4, it means the questionnaire has a better construct validity. In addition, Wang (2018) pointed out that if the KMO values of the measuring questions are above 0.6 and sig. $\leq 0.05$, the questionnaire is suitable for factor analysis. Since the KMO value for the whole questionnaire is 0.836 and sig. $=0.000$, and the KMO value for brand image, purchase intention and consumer ethnocentrism are all over 0.7 and sig. $=0.000$, the 
data is suitable for factor analysis. In the factor analysis (see Table 2), most factor loadings are above 0.7 and some of them are above 0.8 , so the questionnaire is effective.

Table 2. Factor analysis results.

\begin{tabular}{|c|c|c|c|c|c|c|}
\hline Factor & Item & \multicolumn{5}{|c|}{ Factor Loading } \\
\hline \multirow{3}{*}{ Corporate Image } & CI 1 & 0.845 & & & & \\
\hline & $\mathrm{CI} 2$ & 0.788 & & & & \\
\hline & CI 3 & 0.613 & & & & \\
\hline \multirow{3}{*}{ Product Image } & PI 1 & & 0.882 & & & \\
\hline & PI 2 & & 0.664 & & & \\
\hline & PI 3 & & 0.660 & & & \\
\hline \multirow{3}{*}{ User Image } & UI 1 & & & 0.807 & & \\
\hline & UI 2 & & & 0.768 & & \\
\hline & UI 3 & & & 0.691 & & \\
\hline \multirow{3}{*}{ Purchase Intention } & WB 1 & & & & 0.888 & \\
\hline & WB 2 & & & & 0.884 & \\
\hline & WB 3 & & & & 0.870 & \\
\hline \multirow{3}{*}{ Consumer Ethnocentrism } & CE 1 & & & & & 0.916 \\
\hline & $\mathrm{CE} 2$ & & & & & 0.911 \\
\hline & CE 3 & & & & & 0.900 \\
\hline
\end{tabular}

\subsection{Correlation Analysis}

This study applies Pearson correlation coefficient method to analyze the correlation between variables. Table 3, Table 4, Table 5 present the correlation coefficients of the whole sample, domestic brands and foreign brands respectively. According the analyzing statistics shown in the tables, correlation coefficients are all less than 0.6 and most of them are less than 0.5, so the correlation between variables is not high. The highest correlation coefficient is the correlation between the interaction of corporate image and consumer ethnocentrism and the interaction of user image and consumer ethnocentrism with 0.587. Thereby, the data meets the requirements for further regression analysis.

\subsection{Hypothesis Testing}

Table 6 describes the regression analysis for the domestic and foreign laptop brands. As to the results in the Table 6, all Durbin-Watson (DW) values are above 2, which within the range of 1.5 and 2.5 (Lin \& Lu, 2010), so the results obey the normal distribution. In addition, the variance inflation factor (VIF) values for all items are less than 10, so there is no autocorrelation between residual items. According to model 1 (M1), the results presents that the brand image could explain $40.3 \%$ of the variance towards purchase intention; moreover, with the regression coefficient value for corporate image $(\beta=0.283, \mathrm{p}=0.000<0.001)$, product image $(\beta=0.195, \mathrm{p}=0.000<0.001)$ and user image $(\beta=0.334, p=0.000<0.001)$, these three dimensions of brand image reach the statistical significance. Therefore, corporate image, product image and user image can positively influence the purchase intention of college students. As to model 2 (M2), after controlling the demographic factors, consumer ethnocentrism does not influence the purchase intention of college students for buying either domestic laptops or foreign laptops $(\beta=0.084, p=0.107>0.1)$. The results of Model $3(\mathrm{M} 3)$ show that the interaction item between user image and consumer ethnocentrism $(\beta=-0.107, \mathrm{p}=0.03<0.05)$ could have a negative impact on the college students' willingness to buy different brands of laptops. As a result, $\mathrm{H} 1$ and $\mathrm{H} 7$ are supported; however, $\mathrm{H} 4 \mathrm{is} \mathrm{not}$ supported. 


\begin{tabular}{|c|c|c|c|c|c|c|c|c|c|c|c|}
\hline Variable & $G$ & $\mathrm{E}$ & $\mathrm{A}$ & MDI & CI & PI & UI & $\mathrm{CE}$ & $\mathrm{CI} \times \mathrm{CE}$ & $\mathrm{PI} \times \mathrm{CE}$ & $\mathrm{UI} \times \mathrm{CE}$ \\
\hline $\mathrm{G}$ & 1 & & & & & & & & & & \\
\hline $\mathrm{E}$ & $-0.146^{* * *}$ & 1 & & & & & & & & & \\
\hline $\mathrm{A}$ & $-0.109^{*}$ & $0.178^{* * *}$ & 1 & & & & & & & & \\
\hline MDI & 0.049 & -0.030 & $0.381^{* * *}$ & 1 & & & & & & & \\
\hline CI & 0.094 & 0.000 & -0.061 & $0.200^{* *}$ & 1 & & & & & & \\
\hline PI & 0.007 & -0.014 & -0.007 & -0.012 & $0.45 \mathrm{O}^{* *}$ & 1 & & & & & \\
\hline UI & $0.105^{*}$ & -0.031 & -0.069 & 0.098 & $0.472^{* *}$ & $0.279^{* *}$ & 1 & & & & \\
\hline $\mathrm{CE}$ & $-0.111^{*}$ & -0.086 & 0.091 & -0.016 & 0.016 & 0.091 & 0.094 & 1 & & & \\
\hline $\mathrm{CI} \times \mathrm{CE}$ & 0.034 & -0.066 & -0.012 & -0.077 & 0.085 & 0.036 & 0.029 & $0.174^{* *}$ & 1 & & \\
\hline $\mathrm{PI} \times \mathrm{CE}$ & -0.013 & -0.041 & -0.006 & $-0.113^{*}$ & 0.037 & -0.059 & 0.034 & $0.112^{*}$ & $0.481^{* *}$ & 1 & \\
\hline $\mathrm{UI} \times \mathrm{CE}$ & 0.042 & -0.054 & 0.051 & -0.035 & 0.028 & 0.032 & -0.038 & $0.202^{* *}$ & $0.554^{* *}$ & $0.387^{* *}$ & 1 \\
\hline $\mathrm{N}$ & 376 & 376 & 376 & 376 & 376 & 376 & 376 & 376 & 376 & 376 & 376 \\
\hline
\end{tabular}

Notes: G, Gender; E, Education; A, Age; MDI, Monthly Disposable Income; CI, corporate image; PI, product image; UI, user image; CE, consumer ethnocentrism; N, Number of

Sample.
*p $<0.05 ; * * 0.01$

\begin{tabular}{|c|c|c|c|c|c|c|c|c|c|c|c|}
\hline Variable & $\mathbf{G}$ & E & $\mathrm{A}$ & MDI & CI & PI & UI & $\mathrm{CE}$ & $\mathrm{CI} \times \mathrm{CE}$ & $\mathrm{PI} \times \mathrm{CE}$ & $\mathrm{UI} \times \mathrm{CE}$ \\
\hline G & 1 & & & & & & & & & & \\
\hline $\mathrm{E}$ & $-0.177^{*}$ & 1 & & & & & & & & & \\
\hline A & -0.093 & $0.164^{*}$ & 1 & & & & & & & & \\
\hline MDI & 0.078 & -0.077 & $0.353^{*} *$ & 1 & & & & & & & \\
\hline CI & 0.077 & -0.073 & -0.124 & 0.113 & 1 & & & & & & \\
\hline PI & -0.016 & -0.035 & -0.056 & 0.070 & $0.573^{*} *$ & 1 & & & & & \\
\hline UI & 0.080 & -0.135 & -0.103 & 0.018 & $0.457^{* * *}$ & $0.450^{* * *}$ & 1 & & & & \\
\hline $\mathrm{CE}$ & -0.049 & -0.002 & 0.064 & -0.030 & $0.141^{*}$ & $0.142^{*}$ & $0.190^{* * *}$ & 1 & & & \\
\hline $\mathrm{CI} \times \mathrm{CE}$ & 0.136 & -0.007 & -0.045 & -0.105 & $0.242^{*} * *$ & 0.054 & $0.145^{*}$ & $0.237^{*} * *$ & 1 & & \\
\hline $\mathrm{PI} \times \mathrm{CE}$ & 0.048 & 0.085 & -0.06 & $-0.212^{* *}$ & 0.058 & -0.029 & 0.013 & 0.106 & $0.545^{* * *}$ & 1 & \\
\hline $\mathrm{UI} \times \mathrm{CE}$ & 0.128 & -0.026 & -0.040 & -0.055 & 0.138 & 0.011 & 0.100 & $0.216^{* * *}$ & 0.587 *** & 0.537 *** & 1 \\
\hline $\mathrm{N}$ & 194 & 194 & 194 & 194 & 194 & 194 & 194 & 194 & 194 & 194 & 194 \\
\hline
\end{tabular}

Notes: G, Gender; E, Education; A, Age; MDI, Monthly Disposable Income; CI, corporate image; PI, product image; UI, user image; CE, consumer ethnocentrism; N, Number of Sample.

*p $<0.05 ; *$ * $\mathrm{p}<0.01$ 


\begin{tabular}{|c|c|c|c|c|c|c|c|c|c|c|c|}
\hline Variable & $G$ & $\mathrm{E}$ & $\mathrm{A}$ & MDI & CI & PI & UI & $\mathrm{CE}$ & $\mathrm{CI} \times \mathrm{CE}$ & $\mathrm{PI} \times \mathrm{CE}$ & $\mathrm{UI} \times \mathrm{CE}$ \\
\hline $\mathrm{G}$ & 1 & & & & & & & & & & \\
\hline $\mathrm{E}$ & -0.121 & 1 & & & & & & & & & \\
\hline $\mathrm{A}$ & $-0.147 *$ & $0.187^{*}$ & 1 & & & & & & & & \\
\hline MDI & -0.022 & 0.004 & 0.394** & 1 & & & & & & & \\
\hline $\mathrm{CI}$ & 0.065 & 0.068 & -0.040 & $0.222^{* * *}$ & 1 & & & & & & \\
\hline PI & 0.058 & 0.018 & 0.067 & -0.07 & $0.377^{*} *$ & 1 & & & & & \\
\hline $\mathrm{UI}$ & 0.092 & 0.053 & -0.079 & 0.102 & $0.433^{*} *$ & $0.159^{*}$ & 1 & & & & \\
\hline $\mathrm{CE}$ & $-0.164 *$ & $-0.177^{*}$ & $0.146^{*}$ & 0.044 & -0.084 & 0.003 & 0.051 & 1 & & & \\
\hline $\mathrm{CI} \times \mathrm{CE}$ & -0.069 & -0.084 & 0.049 & -0.003 & -0.048 & -0.014 & -0.029 & 0.082 & 1 & & \\
\hline $\mathrm{PI} \times \mathrm{CE}$ & -0.087 & $-0.227 * *$ & 0.108 & 0.036 & -0.014 & $-0.174 *$ & 0.053 & 0.064 & $0.429 * *$ & 1 & \\
\hline $\mathrm{UI} \times \mathrm{CE}$ & -0.029 & -0.025 & $0.165^{*}$ & 0.009 & -0.029 & 0.051 & -0.116 & $0.214 * *$ & $0.466^{* *}$ & $0.246 * *$ & 1 \\
\hline $\mathrm{N}$ & 182 & 182 & 182 & 182 & 182 & 182 & 182 & 182 & 182 & 182 & 182 \\
\hline
\end{tabular}

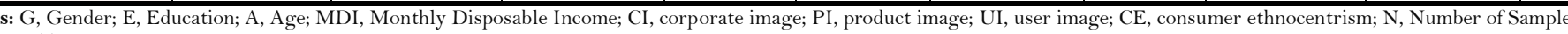

*p $<0.05 ; * * \mathrm{p}<0.01$ 
Table 6. Regression analysis of domestic and foreign brands.

\begin{tabular}{|c|c|c|c|c|c|c|c|}
\hline & $\boldsymbol{\beta}$ & $\mathbf{t}$ & p & VIF & $\mathbf{R}^{2}$ & $\mathbf{F}$ & DW \\
\hline \multicolumn{8}{|c|}{ Control Variables } \\
\hline Gender & 0.094 & 1.810 & 0.071 & 1.037 & \multirow{4}{*}{0.015} & \multirow{4}{*}{$2.432 *$} & \multirow{4}{*}{2.194} \\
\hline Education & 0.070 & 1.334 & 0.183 & 1.060 & & & \\
\hline Age & -0.106 & -1.865 & 0.063 & 1.237 & & & \\
\hline MDI & 0.103 & 1.841 & 0.066 & 1.193 & & & \\
\hline \multicolumn{8}{|l|}{ M1 (H1) } \\
\hline Gender & 0.044 & 1.082 & 0.280 & 1.048 & \multirow{7}{*}{0.403} & \multirow{7}{*}{$37.148^{* * * *}$} & \multirow{7}{*}{2.024} \\
\hline Education & 0.058 & 1.400 & 0.162 & 1.064 & & & \\
\hline Age & -0.023 & -0.515 & 0.607 & 1.276 & & & \\
\hline MDI & -0.014 & -0.301 & 0.763 & 1.291 & & & \\
\hline $\mathrm{CI}$ & $0.283 * * *$ & 5.613 & 0.000 & 1.602 & & & \\
\hline PI & $0.195^{* * * *}$ & 4.299 & 0.000 & 1.293 & & & \\
\hline UI & $0.334^{* * * *}$ & 7.319 & 0.000 & 1.306 & & & \\
\hline \multicolumn{8}{|l|}{$\mathrm{M} 2(\mathrm{H} 4)$} \\
\hline Gender & $0.104 *$ & 1.983 & 0.048 & 1.050 & \multirow{5}{*}{0.019} & \multirow{5}{*}{$2.477^{*}$} & \multirow{5}{*}{2.172} \\
\hline Education & 0.081 & 1.527 & 0.128 & 1.077 & & & \\
\hline Age & $-0.117 *$ & -2.041 & 0.042 & 1.253 & & & \\
\hline MDI & 0.108 & 1.935 & 0.054 & 1.197 & & & \\
\hline $\mathrm{CE}$ & 0.084 & 1.617 & 0.107 & 1.037 & & & \\
\hline \multicolumn{8}{|l|}{ M3 (H7) } \\
\hline Gender & 0.057 & 1.383 & 0.167 & 1.070 & \multirow{11}{*}{0.414} & \multirow{11}{*}{$25.046^{* * * *}$} & \multirow{11}{*}{2.060} \\
\hline Education & 0.054 & 1.321 & 0.187 & 1.085 & & & \\
\hline Age & -0.019 & -0.423 & 0.672 & 1.301 & & & \\
\hline MDI & -0.016 & -0.358 & 0.721 & 1.326 & & & \\
\hline $\mathrm{CI}$ & $0.292^{* * *}$ & 5.799 & 0.000 & 1.627 & & & \\
\hline $\mathrm{PI}$ & $0.201^{* * * *}$ & 4.431 & 0.000 & 1.320 & & & \\
\hline UI & $0.319^{* * * *}$ & 6.981 & 0.000 & 1.334 & & & \\
\hline $\mathrm{CE}$ & 0.038 & 0.904 & 0.367 & 1.108 & & & \\
\hline $\mathrm{CI} \times \mathrm{CE}$ & -0.062 & -1.223 & 0.222 & 1.667 & & & \\
\hline $\mathrm{PI} \times \mathrm{CE}$ & 0.069 & 1.487 & 0.138 & 1.375 & & & \\
\hline $\mathrm{UI} \times \mathrm{CE}$ & $-0.107^{*}$ & -2.181 & 0.030 & 1.531 & & & \\
\hline $\mathrm{N}$ & \multicolumn{7}{|l|}{376} \\
\hline
\end{tabular}

Table 7 shows the regression results for the domestic brands. The DW value for all the items are within the range of 1.5 and 2.5, so the results obey the normal distribution. Moreover, all the VIF values are less than 10, so there is no autocorrelation between residual items. The results in model 4 (M4) indicate that the brand image could interpret $37.9 \%$ of the variance towards purchase intention. In addition, the regression coefficient value for corporate image $(\beta=0.285, \mathrm{p}=0.000<0.001)$, product image $(\beta=0.229, \mathrm{p}=0.002<0.01)$ and user image $(\beta=$ $0.269, \mathrm{p}=0.000<0.001)$, these results mean that brand image can positively affect the purchase intention of college students. According to model 5 (M5), consumer ethnocentrism can have a positive impact on the purchase intention of college students for buying domestic laptops $(\beta=0.199, p=0.006<0.01)$. As to Model 6 (M6), the interaction items between consumer ethnocentrism and three dimensions brand image show no significance, since p-values are all above 0.01. Therefore, H2, H2a, H2b, H2c and H5 are supported, while H8 is not supported.

Table 8 presents the regression results based on the sample of foreign brands. The DW value for all the items are above 2 and less than 2.5, so the results obey the normal distribution. Furthermore, all VIF values are less than 10, so there is no autocorrelation between residual items. The results in model 7 (M7) demonstrate that the brand image, including corporate image, product image and user image, could interpret $40.9 \%$ of the variance towards purchase intention.

In addition, the regression coefficient value for corporate image $(\beta=0.232, p=0.001<0.01)$, product image $(\beta$ $=0.240, \mathrm{p}=0.000<0.001)$ and user image $(\beta=0.365, \mathrm{p}=0.000<0.001)$, so brand image does have a positive 
impact on the purchase intention of college students. According to model 8 (M8), there is no significance of consumer ethnocentrism on the college students' purchase intention of foreign laptops $(\beta=-0.018, p=0.815>$ 0.05). As to the data in the Model 9 (M9), consumer ethnocentrism can negatively moderate the influence of the corporate image on the purchase intention of college students, with the result of $\beta=-0.151$ and $p=0.03<0.05$. Consequently, H3, H3a, H3b, H3c, H6 and H9 are supported.

Table 7. Regression analysis of domestic brands.

\begin{tabular}{|c|c|c|c|c|c|c|c|}
\hline & $\boldsymbol{\beta}$ & 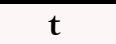 & $\mathbf{p}$ & VIF & $\mathbf{R}^{2}$ & $\mathbf{F}$ & $\mathrm{DW}$ \\
\hline \multicolumn{8}{|c|}{ Control Variables } \\
\hline Gender & 0.064 & 0.867 & 0.387 & 1.047 & \multirow{4}{*}{-0.012} & \multirow{4}{*}{0.449} & \multirow{4}{*}{1.931} \\
\hline Education & 0.048 & 0.646 & 0.519 & 1.074 & & & \\
\hline Age & -0.042 & -0.533 & 0.594 & 1.204 & & & \\
\hline MDI & 0.037 & -0.474 & 0.636 & 1.179 & & & \\
\hline \multicolumn{8}{|c|}{$\mathrm{M} 4(\mathrm{H} 2, \mathrm{H} 2 \mathrm{a}, \mathrm{H} 2 \mathrm{~b}, \mathrm{H} 2 \mathrm{c})$} \\
\hline Gender & 0.047 & 0.805 & 0.422 & 1.057 & \multirow{7}{*}{0.379} & \multirow{7}{*}{$17.798^{* * * *}$} & \multirow{7}{*}{1.809} \\
\hline Education & 0.088 & 1.492 & 0.137 & 1.088 & & & \\
\hline Age & 0.055 & 0.867 & 0.387 & 1.237 & & & \\
\hline MDI & -0.120 & -1.924 & 0.056 & 1.211 & & & \\
\hline $\mathrm{CI}$ & $0.285^{* * *}$ & 3.897 & 0.000 & 1.660 & & & \\
\hline PI & $0.229 * *$ & 3.187 & 0.002 & 1.610 & & & \\
\hline $\mathrm{UI}$ & $0.269^{* * * *}$ & 4.037 & 0.000 & 1.382 & & & \\
\hline \multicolumn{8}{|l|}{ M5 (H5) } \\
\hline Gender & 0.073 & 0.996 & 0.321 & 1.049 & \multirow{5}{*}{0.023} & \multirow{5}{*}{1.926} & \multirow{5}{*}{1.948} \\
\hline Education & 0.054 & 0.731 & 0.466 & 1.075 & & & \\
\hline Age & -0.059 & -0.759 & 0.449 & 1.211 & & & \\
\hline MDI & -0.025 & -0.33 & 0.742 & 1.182 & & & \\
\hline $\mathrm{CE}$ & O.199** & 2.788 & 0.006 & 1.009 & & & \\
\hline \multicolumn{8}{|l|}{ M6 (H8) } \\
\hline Gender & 0.061 & 1.027 & 0.306 & 1.087 & \multirow{11}{*}{0.380} & \multirow{11}{*}{$11.759^{* * *}$} & \multirow{11}{*}{1.866} \\
\hline Education & 0.085 & 1.432 & 0.154 & 1.098 & & & \\
\hline Age & 0.045 & 0.714 & 0.476 & 1.253 & & & \\
\hline MDI & -0.110 & -1.723 & 0.087 & 1.279 & & & \\
\hline CI & $0.289^{* * * *}$ & 3.834 & 0.000 & 1.765 & & & \\
\hline PI & $0.219^{* *}$ & 3.014 & 0.003 & 1.637 & & & \\
\hline UI & $0.263^{* * *} *$ & 3.906 & 0.000 & 1.411 & & & \\
\hline $\mathrm{CE}$ & 0.086 & 1.429 & 0.155 & 1.130 & & & \\
\hline $\mathrm{CI} \times \mathrm{CE}$ & 0.018 & 0.235 & 0.815 & 1.872 & & & \\
\hline $\mathrm{PI} \times \mathrm{CE}$ & 0.046 & 0.630 & 0.529 & 1.686 & & & \\
\hline $\mathrm{UI} \times \mathrm{CE}$ & -0.127 & -1.700 & 0.091 & 1.749 & & & \\
\hline $\mathrm{N}$ & \multicolumn{7}{|l|}{194} \\
\hline
\end{tabular}

\section{DISCUSSION AND IMPLICATIONS}

\subsection{Discussion}

This study theoretically and empirically contributes several important findings to the research regarding the influence of brand image and consumer ethnocentrism on the consuming behaviors of Chinese college students in the laptop industry. Firstly, for the influence of brand image on purchase intention, weather the college students purchase a domestic or foreign brand of laptop, the better the brand image of the laptop, the stronger the students' purchase intention. In other words, if the corporate image, product image and user image of the laptop can satisfy the college students, these students will be willing to buy the laptop. This finding is consistent with some previous research results. For example, Pang and Yang (2014) empirically demonstrated that the corporate image of the laptops can have a remarkable influence on the consuming behavior of consumers, whether the laptop is a domestic or foreign brand. In addition, Zhou (2014) proved that brand image which consists of corporate image, product image and user image can have a positive impact on the consumers' purchase intention of domestic and foreign 
cosmetics. Therefore, this study infers that brand image is one of the main factors driving college students' consuming behaviors when they are purchasing laptops. Companies which have reputable corporate image such as strong research and development capability and scale of business, attractive product image such as cheaper price and various patterns, and reasonable user image (eg. education level, personality) are easy to improve the college students' willingness to buy their products.

Table 8. Regression analysis of foreign brands.

\begin{tabular}{|c|c|c|c|c|c|c|c|}
\hline & $\bar{\beta}$ & $\mathrm{t}$ & $\bar{p}$ & VIF & $\mathbf{R}^{2}$ & $\mathbf{F}$ & $\overline{D W}$ \\
\hline \multicolumn{8}{|l|}{ Control Variables } \\
\hline Gender & 0.102 & 1.380 & 0.169 & 1.033 & \multirow{4}{*}{0.037} & \multirow{4}{*}{$2.752^{*}$} & \multirow{4}{*}{2.100} \\
\hline Education & 0.071 & 0.944 & 0.346 & 1.052 & & & \\
\hline Age & $-0.186^{*}$ & -2.274 & 0.024 & 1.255 & & & \\
\hline MDI & $0.199^{*}$ & 2.494 & 0.014 & 1.192 & & & \\
\hline \multicolumn{8}{|c|}{ M7 (H3, H3a, H3b, H3c) } \\
\hline Gender & 0.040 & 0.681 & 0.497 & 1.044 & \multirow{7}{*}{0.409} & \multirow{7}{*}{$18.906^{* * *} *$} & \multirow{7}{*}{2.015} \\
\hline Education & 0.013 & 0.213 & 0.832 & 1.068 & & & \\
\hline Age & -0.124 & -1.874 & 0.063 & 1.339 & & & \\
\hline MDI & 0.101 & 1.523 & 0.130 & 1.357 & & & \\
\hline $\mathrm{CI}$ & $0.232 * *$ & 3.272 & 0.001 & 1.538 & & & \\
\hline PI & $0.240^{* * * *}$ & 3.759 & 0.000 & 1.246 & & & \\
\hline $\mathrm{UI}$ & $0.365 * * *$ & 5.728 & 0.000 & 1.247 & & & \\
\hline \multicolumn{8}{|l|}{ M8 (H6) } \\
\hline Gender & 0.099 & 1.317 & 0.190 & 1.063 & \multirow{5}{*}{0.032} & \multirow{5}{*}{2.201} & \multirow{5}{*}{2.099} \\
\hline Education & 0.066 & 0.863 & 0.389 & 1.110 & & & \\
\hline Age & $-0.183^{*}$ & -2.201 & 0.029 & 1.288 & & & \\
\hline MDI & O.198* & 2.481 & 0.014 & 1.193 & & & \\
\hline $\mathrm{CE}$ & -0.018 & -0.235 & 0.815 & 1.102 & & & \\
\hline \multicolumn{8}{|l|}{ M9 (H9) } \\
\hline Gender & 0.030 & 0.515 & 0.607 & 1.096 & \multirow{11}{*}{0.423} & \multirow{11}{*}{$13.073^{* * * *}$} & \multirow{11}{*}{2.042} \\
\hline Education & 0.007 & 0.113 & 0.910 & 1.232 & & & \\
\hline Age & -0.115 & -1.695 & 0.092 & 1.445 & & & \\
\hline MDI & 0.101 & 1.531 & 0.128 & 1.370 & & & \\
\hline $\mathrm{CI}$ & $0.220^{* *}$ & 3.106 & 0.002 & 1.570 & & & \\
\hline PI & $0.257 * * * *$ & 3.960 & 0.000 & 1.326 & & & \\
\hline UI & $0.358^{* * * *}$ & 5.530 & 0.000 & 1.317 & & & \\
\hline $\mathrm{CE}$ & -0.029 & -0.465 & 0.642 & 1.182 & & & \\
\hline $\mathrm{CI} \times \mathrm{CE}$ & $-0.151^{*}$ & -2.189 & 0.030 & 1.494 & & & \\
\hline $\mathrm{PI} \times \mathrm{CE}$ & 0.067 & 0.998 & 0.320 & 1.427 & & & \\
\hline $\mathrm{UI} \times \mathrm{CE}$ & -0.043 & -0.641 & 0.522 & 1.406 & & & \\
\hline $\mathrm{N}$ & 182 & & & & & & \\
\hline
\end{tabular}
Sample; $* \mathrm{p}<0.05 ; * * \mathrm{p}<0.01, * * * \mathrm{p}<0.001$.

Secondly, in addition to brand image, consumer ethnocentrism can also positively influence the purchase intention of laptops; however, this effect can be only effective when college students buy domestic products. This finding is consistent with Yen (2018), who stated that Consumer ethnocentrism is positively associated with the willingness of consumers in developing countries to buy domestic products. Generally, consumer ethnocentrism has no effect when college students purchasing laptops, let alone the college students who buy foreign brand laptops. This finding is partially in line with Ding (2017), who empirically noted that consumer ethnocentrism is not the chief concern amongst Chinese consumers' product preference between domestic and foreign products. Furthermore, this study also finds that the level of consumer ethnocentrism of Chinese college students is low. This finding is square with several previous studies (eg. (Ding, 2017; Wang \& Chen, 2004)), which proved that Chinese consumers have low level of consumer ethnocentrism, and even high ethnocentric consumers may buy foreign laptops if the quality of these laptops are higher than that of domestic laptops. Therefore, this study confirms that consumer ethnocentrism is an important factor that drives college students to buy domestic laptops; it can reduce 
the attractiveness of foreign laptops in some college students' minds. On the other hand, for students who have comparatively low or no consumer ethnocentrism, foreign laptop companies are likely to offset the little impact of consumer ethnocentrism by improving their brand image (eg. superior performance, sterling reputation), although it may be not a long-term effective method to stimulate Chinese college students to buy foreign laptops due to the continuous technological progress and more attractive local pricing strategies of Chinese laptop companies.

Thirdly, the influence of consumer ethnocentrism on the relationship between the brand image and the purchase intention of laptops varies with domestic and foreign laptop brands. Specifically, in general, whether the college students purchase domestic or foreign laptop brands, consumer ethnocentrism can negatively moderate the impact of user image on the college students' willingness to buy laptops. In other words, comparing with low or no ethnocentric college students, high ethnocentric college students can restrain the influence of user image on their purchase intention. For example, although the user image of Apple or Lenovo shows the users of this company desire the quality of life and particularly meets some college students' expectations, high consumer ethnocentrism can reduce the influence of user image, thereby mitigate the positive effect of brand image on the purchase intention of college students. This is an innovative finding that quite few researchers have found before. What is more, notably, as to the college students who purchase domestic laptop brands, there is no moderating effect of consumer ethnocentrism on the relationship between brand image and purchase intention. This may be because consumer ethnocentrism is not of the great importance in Chinese college students' minds when shopping (Han, 2017). In other words, compared with low or no ethnocentric college students, the willingness of buying domestic products will not be raised even the college students have high ethnocentrism.

Nevertheless, as to the influence on the choice decisions of foreign laptop brands, consumer ethnocentrism can play a significant role in moderating the relationship between the corporate image and purchase intention of college students. It is novel to find that compared with low or no ethnocentric college students, high ethnocentric college students may be transfer to choose domestic laptop brands such as Huawei or Mi, even though some foreign laptop brands (eg. Apple, Samsung) have large marketing scale, long history, and comparative research and development capabilities. This finding partially proves the statement of $\mathrm{Xu}$ et al. (2017), who suggested that consumer ethnocentrism could significantly change consumer preferences and the consumer preference of high ethnocentric group for domestic and foreign brands can be greatly diminished. Moreover, consumers could reject foreign products on moral and patriotic grounds but not due to lower product quality evaluations in a developing country like China (Ding, 2017). This finding can be an evidence for further research about the moderating effect of consumer ethnocentrism on the relationship between the brand images of foreign products and the consumers' purchase intention in developing countries. Thus, foreign laptop marketers should not do some sensitive events, such as national discrimination and national insulting remarks, for Chinese college students' market, if they want to remain the willingness of college students to buy their products.

\subsection{Implications}

From the theoretical perspective, this study has the following four implications.

(1) This study empirically proved the assumptions that brand image can significantly associated with the willingness of Chinese college students to buy laptops. More importantly, there is no difference between the influence of domestic laptop brand image on the purchase intention of college students and that of foreign laptop brand image on the purchase intention of college students.

(2) This study further ensures that all three dimensions of brand image, which are corporate image, product image and user image, can positively influence the purchase intention of consumers for either the domestic laptop brands or foreign laptop brands. Second, this study proves that the level of consumer ethnocentrism is low among the Chinese college students, which is more detailed than previous researches which took the young people as a sample. 
(3) This study affirms the hypothesis that consumption ethnocentrism has no significant influence on the willingness of college students to buy laptops. However, the results also points out that consumer ethnocentrism is positively related to the purchase intention of college students for domestic laptop brands, while it will become an irrelevant factor when these students are purchasing foreign laptop brands.

(4) Based on the results of this study, consumer ethnocentrism has a moderating effect on the context between brand image and consuming decisions of college students. This finding can partially provide the evidence for the views of Ding (2017), who claimed that consumer ethnocentrism has only moderate influences on young consumers in China. Additionally, it is novel to yield the finding that consumer ethnocentrism can negatively moderate the influence of user image on the purchase intention of college students for different brands of laptops and the impact of corporate image on the purchase intention of college students for the foreign brand laptops.

In addition to the theoretical implications, this study also has four essential practical implications. First, this study reveals that the laptop companies need to improve their brand images of the products so that consumers, especially college students group, can maintain the long-term purchase intention for their products. In addition, it is an effective method to boost their products' brand images through corporate image (eg. research and development capability, world of mouth), product image (eg. price, function) and user image (eg. personality, educational level). Second, this study emphasizes that companies need to catch the business opportunity of consumer ethnocentrism and create some China-style marketing strategies, so that high ethnocentric college students can be easily attracted to buy domestic laptops and become loyal consumers. Third, this study presents the importance of consumer ethnocentrism on the consuming decisions of foreign laptops. It is extremely essential for the foreign investors or marketers, especially those from the laptop industry, to avoid some problems such as insult remarks and discrimination that can cause the national conflict between the home country and China, and thereby ignite the anger of consumers in China. Otherwise, no matter how favorable the corporate image the laptop has, Chinese college students would not buy this laptop due to the negative moderating effect of consumer ethnocentrism. At last, foreign laptop companies also need to improve their brand image of products, so that the influence of consumer ethnocentrism can be mitigated.

\section{CONCLUSIONS}

The purpose of this study is to research the influence of brand image, consumer ethnocentrism on the college students' willingness to buy laptops and the moderating effect of consumer ethnocentrism on the influence of laptop brand image on the purchase intention of college students. Through examination and comparison, this study confirms that brand image has a positive impact on the college students' purchase intention for laptops, regardless of the laptop is a domestic or foreign brand. In addition, consumer ethnocentrism generally does not influence the purchase intention of college students for different brands of laptops; nevertheless, it can be positively associated with college students' purchase intention of domestic laptop brands. Furthermore, this study also proves that consumer ethnocentrism can have a negative moderating effect on the influence of the laptops' user image on college students' purchase intention, regardless of domestic or foreign laptop brands. Moreover, consumer ethnocentrism is not the chief concern for college students when they purchase domestic laptops; however, it can play a significant moderator role when college students choose foreign laptops; in detail, compared with low or no ethnocentrism, the influence of corporate image on the college students' willingness to buy foreign laptops can be reduced with high consumer ethnocentrism.

Funding: This study received no specific financial support.

Competing Interests: The authors declare that they have no competing interests.

Authors' Contributions: All authors contributed equally to the conception and design of the study. 


\section{REFERENCES}

Andreassen, T. W., \& Lindestad, B. (1998). Customer loyalty and complex services: The impact of corporate image on quality, customer satisfaction and loyalty for customers with varying degrees of service expertise. International Journal of Service Industry Management, 9(1), 7-23. Available at: https://doi.org/10.1 108/09564239810199923.

Bearden, W. O., \& Etzel, M. J. (1982). Reference group influence on product and brand purchase decisions. Journal of Consumer Research, 9(2), 183-194. Available at: https://www.jstor.org/stable/2489127.

Bian, X., \& Moutinho, L. (2011). The role of brand image, product involvement, and knowledge in explaining consumer purchase behaviour of counterfeits: Direct and indirect effects. European Journal of Marketing, 45(1/2), 191-216. Available at: https://doi.org/10.1108/03090561111095658.

Biel, A. L. (1992). How brand image drives brand equity. Journal of Advertising Research, 32(6), 6-12.

Cai, J. H. (2009). Research on consumer perceived value and purchase decision based on Cue Utilization Theory - Target college notebook market. [Unpublished Master's Thesis]. Xiamen University.

Cao, Y., \& Fu, G. Q. (2012). Consumer evaluations of brand extensions: The influences of brand user image. Chinese Journal of Management, 9(5), 723-728. Available at: http://kns.cnki.net/kns/brief/default_result.aspx.

Cian, L., \& Cervai, S. (2014). Under the reputation umbrella: An integrative and multidisciplinary review for corporate image, projected image, construed image, organizational identity, and organizational culture. Corporate Communications: An International Journal, 19(2), 182-199. Available at: https://doi.org/10.1108/CCIJ-10-2011-0055.

Ding, Q. S. (2017). Chinese products for Chinese people? Consumer ethnocentrism in China. International Journal of Retail \& Distribution Management, 45(5), 550-564. Available at: https://doi.org/10.1 108/IJRDM-1 1-2016-02 12.

Evanschitzky, H., Wangenheim, F. v., Woisetschläger, D., \& Blut, M. (2008). Consumer ethnocentrism in the German market. International Marketing Review, 25(1), 7-32. Available at: https://doi.org/10.1 108/02651330810851863.

Han, C. M. (2017). Cosmopolitanism and ethnocentrism among young consumers in emerging Asia: Chinese vs Koreans towards Japanese brands. Asia Pacific Journal of Marketing and Logistics, 29(2), 330-346. Available at: https://doi.org/10.1 108/APJML-07-2016-0113.

IRsearch Consulting Group. (2016). 2015 Chinese undergraduate students consumption installments Report. Retrieved from: https:// www.iresearch.com.cn/Detail/report?id=2512\&isfree $=0$.

Jiao, L. (2007). Comparative research for Chinese and foreign mobile phone brand image - substantial evidence research according to A.L.Biel Model: Shandong University.

Johansson, U., Koch, C., Varga, N., \& Zhao, F. (2018). Country of ownership change in the premium segment: Consequences for brand image. Journal of Product and Brand Management, 27(7), 871-883. Available at: https://doi.org/10.1 108/JPBM10-2017-1651.

Keller, K. L. (1993). Measuring, and managing customer-based brand equity Journal of Marketing, 57(1), 1-22. Available at: https://www.jstor.org/stable/1252054.

Lee, R., Lee, K. T., \& Li, J. (2017). A memory theory perspective of consumer ethnocentrism and animosity. European Journal of Marketing, 51(7/8), 1266-1285. Available at: https://doi.org/10.1108/EJM-03-2014-0188.

Lee, T. S., Leung, C. S., \& Zhang, Z. M. (2000). Fashion brand image marketing: Brand image and brand personality. Research Journal of Textile and Apparel, 4(2), 60-67. Available at: https://doi.org/10.1 108/RJTA-04-02-2000-Bo08

Liang, Y. T. (2015). The study of the impact of shopping site brand image on consumer brands attitudes and purchase intention. [Unpublished Master's Thesis]. South China University of Technology.

Lin, L. Y., \& Lu, C. Y. (2010). The influence of corporate image, relationship marketing, and trust on purchase intention: The moderating effects of word-of-mouth. Tourism Review, 65(3), 16-34. Available at: https://doi.org/10.1108/16605371011083503.

Mai, Z. J. (2013). The research on impact of sport shoes brand image on customers' purchase intention. [Unpublished Master's Thesis]. South China University of Technolog. 
Ministry of Education of the People's Republic of China. (2018). Number of students of formal education by type and level. Retrieved from: http://www.moe.gov.cn/s78/A03/moe_560/jytjsj_2017/ (Accessed 16 April, 2019).

Nöth, W. (1988). The language of commodities Groundwork for a semiotics of consumer goods. International Journal of Research in Marketing, 4(3), 173-186. Available at: https://doi.org/10.1016/S0167-8116(88)80003-X.

Ogba, I. E., \& Tan, Z. (2009). Exploring the impact of brand image on customer loyalty and commitment in China. Journal of Technology Management in China, 4(2), 132-144. Available at: https://doi.org/10.1 108/17468770910964993.

Pang, L., \& Yang, X. W. (2014). The influence of brand image on consumer purchase behavior research — on the notebook industry. Future and Development, 38(8), 66-73.

Peng, Y. X. (2017). An empirical study on the impact of brand image on consumers' purchase intention in the study broad training industryA case of Shenzhen. [Unpublished Master's Thesis]. Shenzhen University.

Plumeyer, A., Kottemann, P., Böger, D., \& Decker, R. (2019). Measuring brand image: A systematic review, practical guidance, and future research directions. Review of Managerial Science, 13(2), 227-265. Available at: https://doi.org/10.1007/s11846-017-0251-2.

Ran, N. (2010). An empirical study of consumer ethnocentrism-Based on comparison between middle school students and college students. China Youth Study, 02, 5-9.

Reardon, J., Miller, C., Vida, I., \& Kim, I. (2005). The effects of ethnocentrism and economic development on the formation of brand and ad attitudes in transitional economies. European Journal of Marketing, 39(7/8), 737-754. Available at: https://doi.org/10.1108/03090560510601743.

Saunders, M., Lewis, P., \& Thornhill, A. (2010). Research methods for business students (5th ed.): Dongbei University of Finance and Economics Press.

Shimp, T. A., \& Sharma, S. (1987). Consumer ethnocentrism: Construction and validation of the CETSCALE. Journal of marketing research, 24(3), 280-289. Available at: https:// www.jstor.org/stable/3151638.

Souiden, N., Ladhari, R., \& Chang, L. (2018). Chinese perception and willingness to buy Taiwanese brands: The role of ethnocentrism and animosity. Asia Pacific Journal of Marketing and Logistics, 30(4), 816-836. Available at: https://doi.org/10.1108/APJML-09-2017-0203.

Tian, M. X. (2014). The study about the brand image of watch reflection on consumer's purchase intentions' Effect” Liaoning University.

Tong, X., \& Li, C. (2013). Impact of brand personality and consumer ethnocentrism in China's sportswear market. Asia Pacific Journal of Marketing and Logistics, 25(3), 491-509. Available at: https://doi.org/10.1 108/APJML-08-2012-0081.

Wang, C. L., \& Chen, Z. X. (2004). Consumer ethnocentrism and willingness to buy domestic products in a developing country setting: Testing moderating effects. Journal of consumer Marketing, 21(6), 391-400. Available at: https://doi.org/10.1108/07363760410558663.

Wang, X. X. (2011). Product identity and brand building. [Unpublished Master's Thesis]. Jilin University.

Wang, J. (2018). The influence of the brand image of convenience store on consumers' purchasing intention - Based on the view of brand identity. [Unpublished Master's Thesis]. Shanxi University of Finance and Economics.

Wang, N. N. (2018). An empirical study on the influence of laptop brand image on college students' purchasing behavior. [Unpublished Master's Thesis]. Heilongjiang University.

Wei, Y. (2008). Does consumer ethnocentrism affect purchase intentions of Chinese consumers? Mediating effect of brand sensitivity and moderating effect of product cues. Journal of Asia Business Studies, 3(1), 54-66. Available at: https://doi.org/10.1108/15587890880000491(Accessed.

Xu, Y. J., Xu, Z. D., Chen, Y. S., \& Wang, J. H. (2017). Origin, brand and national-brand consciousness: Effects of original country in infant formula Milk Powder. Economic Survey, 34(4), 86-91. Available at: http://kns.cnki.net/kns/brief/default_result.aspx.

Xue, F. (2018). Research on fashion brand image building from the perspective of cultural influences. [Unpublished Master's Thesis]. Jiangnan University.

Yang, D. M. (2006). Study on the identity system of product with brand. [Unpublished Master's Thesis]. Tongji University. 
Yang, Y.-W., \& Sun, G.-H. (2013). The impact of country brand image, corporate brand image, and product brand image on consumer's attitude and purchase intention-base on the data of sports brand. Economic Management, 35(1), 99-109.

Yen, Y.-S. (2018). Extending consumer ethnocentrism theory: The moderating effect test. Asia Pacific Journal of Marketing and Logistics, 30(4), 907-926. Available at: https://doi.org/10.1108/APJML-09-2017-0226.

Zhou, C. M. (2014). Research on the influence of telephone brand image on consumers' willingness to buy — from the perceived risk perspective in network environment [Unpublished Master's Thesis]. Nanjing Normal University. 